\title{
LASP1 wt Allele
}

National Cancer Institute

\section{Source}

National Cancer Institute. LASP1 wt Allele. NCI Thesaurus. Code C97605.

Human LASP1 wild-type allele is located within 17q11-q21.3 and is approximately $52 \mathrm{~kb}$ in length. This allele, which encodes LIM and SH3 domain protein 1, plays a role in the modulation of ion transport along microfilaments. A chromosomal translocation $\mathrm{t}(11 ; 17)$ ( $q 23 ; q 21$ ) of this gene and the MLL gene is associated with acute myelomonocytic leukemia. 